Original Article

\title{
Phytochemical composition and biological activities of extracts from ten species of the family Melastomataceae Juss
}

\author{
Composição fitoquímica e atividades biológicas de extratos de dez espécies da família \\ Melastomataceae Juss
}

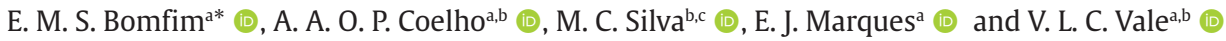 \\ a Universidade do Estado da Bahia - UNEB, Departamento de Ciências Exatas e da Terra, Alagoinhas, BA, Brasil \\ ${ }^{\mathrm{b}}$ Universidade do Estado da Bahia - UNEB, Programa de Pós-graduação em Biodiversidade Vegetal - PPGBV, Senhor do Bonfim, BA, Brasil \\ c Universidade do Estado da Bahia - UNEB, Departamento de Ciências da Vida, Salvador, BA, Brasil
}

\begin{abstract}
Plants possess a renewable source of metabolites with enormous chemical structural diversity, which may have potential therapeutic relevance. Furthermore, this chemical diversity favors the possibility of finding new and different chemical constituents with antimicrobial, antioxidant and anti-tumor activities. This work analyzed preliminary phytochemical profiles and evaluated the antimicrobial, antioxidant and cytotoxic activities of hexane extracts of leaves of ten species of the family Melastomataceae. Phytochemical screening was performed using staining methods while total phenols and flavonoids were quantified by spectrophotometry. Antimicrobial activity was evaluated using the disk diffusion method. Antioxidant activity was determined by the 2,2-diphenyl-1picrylhydrazil (DPPH) method. Toxicity was recorded using the lethality test with Artemia salina Leach (1819). Cytotoxic activity of the extracts was assessed in vitro with acute monocytic leukemia cells (THP-1). Phytochemical analysis detected the presence of tannins, terpenes, steroids, polyphenols and flavonoids and the absence of alkaloids. Clidemia capitellata (Bonpl.) D. Don had the greatest amount of polyphenols ( $205.95 \mathrm{mg} / \mathrm{g} \pm 4.14$ ) while Clidemia hirta (L.) D. Don had the highest content of total flavonoids ( $143.99 \mathrm{mg} / \mathrm{g} \pm 4.18$ ). The hexane extracts did not show antimicrobial activity nor toxicity against Artemia salina. The extract of Tibouchina francavillana Cogn. was the most active in sequestering the DPPH radical. The extracts showed cytotoxicity in THP- 1 cells with the appearance of apoptotic bodies and cell death. The extracts of Miconia amoena, Clidemia sericea and Clidemia capitellata are non-toxic against Artemia salina and induce the formation of apoptotic bodies and cell death of the THP-1 lineage.
\end{abstract}

Keywords: antioxidant activity, antimicrobial activity, polyphenols, THP-1 lineage, Artemia salina.

\begin{abstract}
Resumo
Os vegetais apresentam uma fonte renovável de metabólitos com enorme diversidade química estrutural, os quais podem apresentar potencial relevante na terapêutica, aumentando as possibilidades de encontrar novos e diferentes constituintes químicos com atividades antimicrobiana, antioxidante e antitumoral. Este trabalho analisou o perfil fitoquímico preliminar e as atividades antimicrobiana, antioxidante, citotóxica dos extratos em hexano das folhas de dez espécies da família Melastomataceae. A triagem fitoquímica foi executada utilizando métodos de coloração e quantificação de fenóis e flavonoides totais por espectrofotometria. A atividade antimicrobiana foi realizada pelo método de difusão em disco. A atividade antioxidante foi determinada pelo método 2,2-difenil1-picrilhidrazila (DPPH). A toxicidade foi registrada utilizando o ensaio de letalidade com Artemia salina Leach (1819). A atividade citotóxica dos extratos foi realizada in vitro com células leucêmicas monocítica aguda (THP-1). A análise fitoquímica detectou a presença de taninos, terpenos, esteroides, polifenóis, flavonoides e ausência de alcaloides. A maior quantificação de polifenóis foi da Clidemia capitellata (Bonpl.) D. Don $(205,95 \mathrm{mg} / \mathrm{g} \pm 4,14)$ e 0 extrato de Clidemia hirta (L.) D. Don apresentou maior teor de flavonoides totais $(143,99 \mathrm{mg} / \mathrm{g} \pm 4,18)$. Os extratos hexânicos não demostraram atividade antimicrobiana e nem toxicidade frente à Artemia salina. $\mathrm{O}$ extrato de Tibouchina francavillana Cogn. foi o mais ativo no sequestro do radical DPPH. Os extratos apresentaram citotoxicidade em células THP-1, com visualização de corpos apoptóticos e morte celular. Os extratos de Miconia amoena, Clidemia sericea e Clidemia capitellata são atóxicos contra Artemia salina e induzem a formação de corpos apoptóticos e morte celular da linhagem THP-1.
\end{abstract}

Palavras-chave: atividade antioxidante, atividade antimicrobiana, polifenóis, linhagem THP-1, Artemia salina.

*e-mail: ellen.matos1@gmail.com

Received: August 10, 2020 - Accepted: November 22, 2020

This is an Open Access article distributed under the terms of the Creative Commons Attribution License, which permits unrestricted use, distribution, and reproduction in any medium, provided the original work is properly cited. 


\section{Introduction}

The increased incidence of bacterial resistance, which has been intensified by the extensive and indiscriminate use of broad-spectrum antibiotics, has raised an urgent need for antimicrobial screening (Eloff and McGaw, 2006). Targeted investigations of plant products increase the chances of finding new and different chemical constituents with antimicrobial activities since plants have a renewable source of metabolites with enormous structural chemical diversity, which may have potential therapeutic relevance (França, 2017).

On the other hand, deleterious effects to DNA, proteins, lipids and other tissue biomolecules resulting from the excess production of free radicals in the human body have been indicated as being responsible for the development of chronic and degenerative diseases such as cancer and premature aging (Gonçalves et al., 2005). Antioxidants of plant origin have been established as an important exogenous factor in combating the cumulative effects of free radicals and, thus, reducing damage to the body (Sies, 1993).

The family Melastomataceae of the order Myrtales Juss. ExBercht. \& J. Presl, possesses about 5,000 species distributed among 170 genera (Almeda et al., 2016). In Brazil, the country with the greatest number of flowering plant species in the world, Melastomataceae is the fifth most represented group of angiosperms, with about 73 genera and 1,481 species (JBRJ, 2020).

Studies of the biological potential of the family Melastomataceae have demonstrated that its species have analgesic, antioxidant, antimicrobial, anti-inflammatory activities (Vasconcelos et al., 2006; Andreo et al., 2006; Sobrinho et al., 2017; Bomfim et al., 2020). These activities may be associated with the presence of several secondary metabolites such as flavonoids, tannins, terpenes and anthocyanidins (Calderón et al., 2002; Serna and Martínez, 2015; Bomfim et al., 2020) which are synthesized by plants in response to environmental conditions and often during specific stages of their development. Polyphenols can act by damaging and altering the permeability of the bacterial cell membrane (Cushnie and Lamb, 2005) and combating oxidative stress. Terpenes (Trombetta et al., 2005) and tannins (Scalbert, 1991) inactivate bacterial enzymes. Alkaloids, saponins, lignoids have antitumor and antimutagenic activities (Marques and Lopes, 2015; Lee and Hwangb, 2004; Ardalani et al., 2017).

The present study aimed determine the phytochemical profile of hexane extracts of leaves and evaluate the antimicrobial, antioxidant and cytotoxic activities of leaves of Miconia albicans (Sw.) Triana, Miconia ciliata (Rich.) DC., Miconia fallax DC., Miconia amoena Triana, Miconia alborufescens Naudin, Clidemia hirta (L.) D. Don, Clidemia sericea D. Don, Clidemia capitellata (Bonpl.) D. Don, Tibouchina lhotzkyana (C. Presl) Cogn. and Tibouchina francavillana Cogn.

\section{Material and Methods}

\subsection{Plant material}

Aerial parts of the studied plant species were collected in a remnant of Atlantic Forest in the municipality of Alagoinhas, state of Bahia, Brazil (12 ${ }^{\circ} 10^{\prime} 42.62^{\prime \prime} \mathrm{S}$, $38^{\circ} 24^{\prime} 39.52^{\prime} \mathrm{W}$ ). The leaves were dried in an oven at 48 $50{ }^{\circ} \mathrm{C}$ for 24 horas, manually pulverized and macerated with hexane. The solvent was in contact with the plant material for 72 hours until first filtration, which was repeated three times. The filtrate was then evaporated at room temperature and the extracts stored at $4{ }^{\circ} \mathrm{C}$ until time of analysis.

Voucher exsiccates for the studied species were deposited at Herbário da Universidade do Estado da Bahia (HUNEB), collection Alagoinhas, Bahia, Brazil: Miconia albicans (14025); Miconia ciliata (14036); Miconia fallax (14022); Miconia amoena (14024); Miconia alborufescens (14023); Clidemia hirta (13982); Clidemia sericea (13517); Clidemia capitellata (7685); Tibouchina lhotzkyana (13981) and Tibouchina francavillana (13984).

\subsection{Phytochemical profile}

The samples were analyzed for the presence of alkaloids (Petruczynik, 2012), terpenes and steroids (Harbone, 1998) using thin layer chromatography (CCD). Total phenolic compounds were quantified spectrophotometrically using the Folin-Ciocalteu reaction (Singleton et al., 1999). The absorbance reading of the samples was performed at $620 \mathrm{~nm}$ with a UV-Vis spectrophotometer. The same preparation conditions were used to construct the calibration curve for gallic acid $(y=3.8883 x+0.11141$; $\mathrm{R}^{2}=0.9954$ ) (Bomfim et al., 2020). The results were expressed in milligrams of gallic acid per gram of crude extract (mg EAG/g of extract). Total flavonoids was determined according to the method described by ArvouetGrand et al. (1994). The content of total flavonoids was measured at $492 \mathrm{~nm}$ with a UV-Vis spectrophotometer and expressed in milligrams of quercetin per gram of crude extract (mg EQ/g of extract). The standard quercetin curve was obtained under the same sample preparation conditions $\left(y=1.2078 x-0.1175 ; R^{2}=0.9889\right)$ (Bomfim et al., 2020).

\subsection{In vitro evaluation of antimicrobial activity}

Antimicrobial activity was evaluated by the agar discdiffusion technique (CLSI, 2003), against the bacteria Staphylococcus aureus (ATCC 6538), Pseudomonas aeruginosa (ATCC 15442), Escherichia coli (ATCC 94863), Micrococus luteus (ATCC 10240) and Bacillus subtilis (ATCC 6633). Sterile 6-mm filter paper discs impregnated with $10 \mu \mathrm{L}$ of plant extract $(100.0 \mathrm{mg} / \mathrm{mL})$ were used and chloramphenicol (0.1\%) and DMSO ( $4 \%$ ) served as controls. The plates were incubated in an oven at $37^{\circ} \mathrm{C}$ for 24 hours. The results were read by measuring the inhibition halos of bacterial growth (in $\mathrm{mm}$ ) and comparing them to their respective controls. The test was performed in triplicate and repeated. The final result was the average of the halo measurements.

\subsection{In vitro evaluation of antioxidant activity}

Antioxidant activity of the extracts was evaluated according to Brand-Willians et al. (1995), through capture assay of the free radical 2,2-diphenyl-1-picrylhydrazil (DPPH). $50 \mu \mathrm{L}$ of the samples diluted in ethanol 
(6.0 mg / mL), were transferred to microplates containing $150 \mu \mathrm{L}$ of ethanol. Subsequently, serial dilutions were performed and. $100 \mu \mathrm{L}$ of the DPPH solution $(0.5 \mathrm{mM})$ was added to each well. The plates were kept protected from light at room temperature for 1 hour, after which absorbance readings were performed at $492 \mathrm{~nm}$ with a UV-Vis spectrophotometer. The percentage of free radical scavenging (\% SRL) was determined using the equation used by Moreira et al. (2005).

\subsection{Toxicological test with Artemia salina Leach (1819)}

The toxicity assay of the extracts was performed according to the methodology proposed by Meyer et al. (1982), with adaptations. The extracts were tested in final concentrations of $10 \mu \mathrm{g} / \mathrm{mL}, 100 \mu \mathrm{g} / \mathrm{mL}$ and $1000 \mu \mathrm{g} / \mathrm{mL}$. Saline water and DMSO (1.0\%) were used as control groups. All wells were subjected to artificial lighting. Individuals killed after 24 and 48 hours of exposure to the different concentrations were counted. The program GraphPadPrism 5.0 was used to obtain the average lethal concentration $\left(\mathrm{CL}_{50}\right)$.

\subsection{Lineages and cell culture}

Acute monocytic leukemia cell lineage (THP-1) was cultured in RPMI $(5.0 \mathrm{~mL})$ supplemented with $10 \%$ $\mathrm{v} / \mathrm{v}$ fetal bovine serum (PBS) and $20 \mu \mathrm{g} / \mathrm{mL}$ penicillin/ streptomycin (1\%), obtained from Cultilab. The cultures were replicated, sown and cultivated until confluence in a $25 \mathrm{~cm}^{2}$ culture bottles at $37{ }^{\circ} \mathrm{C}$ in a $5 \%$ $\mathrm{CO}_{2}$ atmosphere and controlled humidity. The THP-1 lineage was donated by Laboratório de Imunologia of Instituto de Ciências da Saúde (ICS) of Universidade Federal da Bahia.

\subsection{Preliminary in vitro evaluation of cytotoxicity of plant extract to THP-1}

Plant extracts were diluted in DMSO $(100 \mu \mathrm{g} / \mathrm{mL})$ and added to plates containing THP- 1 cells $\left(1 \times 10^{6} /\right.$ well) in a volume of $1 \mathrm{~mL}$ of complete RPMI medium. The cells were incubated for 24 hours at $37^{\circ} \mathrm{C}$. After the cell culture period, cell morphology was evaluated using an inverted microscope (20x). Each test was accompanied by a control group containing cells with RPMI and wells containing cells with RPMI and DMSO (0.5\%).

\subsection{Statistical analysis}

The results were expressed as the mean of three repetitions \pm the standard deviation. The distribution of the groups was tested by the Kolmogorov-Smirnov and compared by One-way ANOVA followed by Duncan test at a 5\% significance variable, using GraphPadPrism 5.0, IBM SPSS statistics and Minitab 18. The statistical analysis of the sample mean was performed in separate groups of total phenols, total flavonoids and percentage of sequestered free radicals.

\section{Results}

Phytochemical analysis of the extracts detected tannins, terpenes and steroids. The extract of Clidemia capitellata had a higher content of total phenols with a value of $205.95 \mathrm{mg}$ EAG/g. For quantification of total flavonoids, the extract of Clidemia hirta showed higher content with $143.99 \mathrm{mg}$ EQ/g, as shown in Table 1.

The hexane extracts of the studied plant species did not show antimicrobial activity, under the conditions of the test used. The results of the antioxidant activity, shown in Table 1 , reveal that $60 \%$ of the evaluated extracts exhibit free radical scavenging activity equal to or greater than $25 \%$, which was considered significant. The most active extracts in DPPH radical sequestration were Tibouchina francavillana $(80.64 \% \pm 0.90)$, followed by Miconia alborufescens $(68.33 \% \pm 1.01)$.

In the statistical analysis, the means of the samples didn't show significant difference for the groups of total phenols, total flavonoids and percentage of free radicals.

Table 1. Phytochemical profile and in vitro free radical scavenging activity of leaf extracts from ten species of the family Melastomataceae.

\begin{tabular}{|c|c|c|c|c|c|c|}
\hline Sample & $\begin{array}{c}\text { Total phenols (mg } \\
\text { EAG/g) }\end{array}$ & $\begin{array}{l}\text { Total flavonoids } \\
\text { (mg EQ/g) }\end{array}$ & Al & Ta & Ter/Ste & \%SFR \\
\hline Miconia albicans & $92.90 \pm 4.44$ & $67.4 \pm 1.38$ & - & + & + & $36.48 \pm 2.29$ \\
\hline Miconia ciliata & $84.08 \pm 3.29$ & $38.38 \pm 0.23$ & - & + & + & $1.01 \pm 0.68$ \\
\hline Miconia fallax & $170.97 \pm 3.65$ & $60.82 \pm 1.24$ & - & + & + & $15.07 \pm 2.41$ \\
\hline Miconia amoena & $26.59 \pm 1.98$ & $48.41 \pm 1.52$ & - & + & + & $17.51 \pm 1.62$ \\
\hline Miconia alborufescens & $188.62 \pm 4.72$ & $128.49 \pm 2.80$ & - & + & - & $68.33 \pm 1.01$ \\
\hline Clidemia hirta & $153.72 \pm 5.86$ & $143.99 \pm 4.18$ & - & + & - & $65.70 \pm 1.34$ \\
\hline Clidemia sericea & $166.86 \pm 3.33$ & $55.90 \pm 0.51$ & - & + & + & $13.52 \pm 1.09$ \\
\hline Clidemia capitellata & $205.95 \pm 4.14$ & $124.9 \pm 2.07$ & - & + & + & $67.16 \pm 1.56$ \\
\hline Tibouchina francavillana & $118.26 \pm 3.56$ & $104.8 \pm 2.87$ & - & + & - & $80.64 \pm 0.90$ \\
\hline Tibouchina lhotzkyana & $79.28 \pm 4.75$ & $78.03 \pm 4.84$ & - & + & + & $68.05 \pm 0.16$ \\
\hline
\end{tabular}

Al: alkaloids; Ta: tannins; Ter/Ste: terpenes/steroids; (-) absence; (+) presence; (\% SFR): percentage of sequestered free radicals. 
The hexane extracts did not show toxicity towards Artemia salina in the tested concentrations. Only extracts form Miconia amoena, Clidemia sericea and Clidemia capitellata induced the formation of apoptotic bodies and cell death in the THP-1 lineage.

\section{Discussion}

Plants are a renewable source of chemical compounds with great structural diversity (Kreis et al., 2017), with many constituting therapeutic components for various diseases or serving as a basis for the development of alternative pharmacological products (França, 2017). Despite the different biological applications attributed to products originating from plants, they still represent an exhaustive opportunity for further investigations (Atanasov et al., 2015).

Phytochemical evaluations of species of Melastomataceae have revealed the presence of phenolic compounds, triterpenes, steroids, anthocyanins, saponins, organic acids, tannins, anthraquinones and benzoquinones among their constituents as secondary metabolites (Jones et al., 1980; Santos and Tavares, 2003; Serna and Martínez, 2015; Bomfim et al., 2020). The solvent and extractive method used can influence variation in the levels of total phenols and total flavonoids present in extracts (Oliveira et al., 2016), as well as in biological activity.

Dianita et al. (2011) evaluated the antimicrobial activity of hexane, ethyl acetate and methanol extracts of Clidemia hirta, and found that only the hexane extract did not have activity. Santos et al. (2012) showed promising antimicrobial results for ursolic acid and oleonic acid, isolated from dichloromethane extract of Tibouchina candoleana, against the endodontic bacterium Bacteroides flagilis. Celotto et al. (2003) evaluated the antimicrobial activity of hexane, dichloromethane and ethanol extracts from three species of Miconias and found the ethanol extracts of Miconia albicans and M. rubiginosa to be active against five of the ten species of bacteria evaluated and against Candida albicans; Miconia stenostachia only showed activity for $C$. albicans.

The present work also did not observe any antimicrobial activity for the hexane extracts of the ten evaluated species. Analyses with the ethyl acetate extract of Clidemia hirta and C. capitellata, however, demonstrated antibacterial activity against M. luteus, S. aureus, $P$. aeruginosa and B. subtilis (Bomfim et al., 2020). These results corroborate those of other studies (Dianita et al., 2011; Celotto et al., 2003).

The extracts that showed greater antioxidant activity had higher phenolic contents, corroborating previous studies for the family Melastomataceae (Bomfim et al., 2020). Research has demonstrated the direct correlation between the presence of phenolic compounds and antioxidant activity (Zielinski et al., 2014; Rani et al., 2018). During the capture and neutralization of oxidizing species, phenolic compounds form stable intermediates without causing damage to cell structures due to the resonance of the aromatic ring present in these compounds (Soares, 2002). Other studies, with different types of metabolites, triterpenes, flavonoids and steroids, isolates of Tibouchina granulosa for Pérez-Castorena (2014) and Tibouchina urvilleana by Amzar and Iqbal (2017), showed anti-inflammatory activity. Amzar and Iqbal (2017) reported a hepatoprotective effect of the aqueous extract of Clidemia hirta, a property that was attributed to the antioxidant effect and the capacity for scavenging free radicals observed for the extract.

The hexane extracts of the plant species studied here did not demonstrate toxicity towards Artemia salina at the tested concentrations. A similar result, although with methanolic extract, was recorded by Alves et al. (2000) for leaves of Miconia albicans. On the other hand, Coe et al. (2010) recorded activity for the aqueous extract of Tibouchina aspera. According to the literature, the negative results suggest the absence of cytotoxic compounds in sufficient concentrations to allow trypanomicidal and anti-tumor activities (Mclaughlin et al., 1991), among others. However, the hexane extracts from Miconia amoena, Clidemia serice $a$ and $C$. capitellata were found here to induce the formation of apoptotic bodies and cell death in the THP1 lineage, which is an important feature in the treatment of leukemias (Portt et al., 2011). This, therefore, evidences the antitumor potential of species of Melastomataceae, as also shown by Narasimham et al. (2017) for ethanol extract of Clidemia hirta against tumor cells of the Dalton's lymphoma ascites lineage; by Silva et al. (2016) for ethanol extract of Miconia munutiflora against cancerous cells of human liver (HepG2) and human leukemia (HL60) lineages, in a study of plants form Northeast Brazil; and by Cunha et al. (2008) for ethanol extract of Miconia fallax on tumor cells of the human uterine adenocarcinoma (HeLa) lineage.

\section{Conclusion}

This study provides important results regarding the extracts of Miconia amoena, Clidemia sericea and Clidemia capitellata for being atoxic against Artemia salina and for inducing the formation of apoptotic bodies and cell death of the THP-1 lineage. In addition, most of the extracts showed significant antioxidant capacities and can be considered good natural antioxidants. Nonetheless, future trials using fractions and substances isolated from the extracts should be conducted to corroborate and ensure the results presented here.

\section{Acknowledgements}

To the Bahia Research Support Foundation(FAPESB); To the State University of Bahia (UNEB); To the Chemistry Institute of the Federal University of Bahia; The team of the Laboratory of Organic Chemistry of UNEB, Campus I, Salvador - BA. The team of the Laboratory of Immunology and Molecular Biology of the Institute of Health Sciences, Federal University of Bahia

\section{References}

ALMEDA, F., MICHELANGELI, F.A. and VIANA, P.L., 2016. Brasilianthus (Melastomataceae), a new monotypic genus endemic to ironstone outcrops in the Brazilian Amazon. Phytotaxa, vol. 273, no. 4, pp. 269-282. http://dx.doi.org/10.11646/phytotaxa.273.4.3. 
ALVES, T.M.A., SILVA, A.F., BRANDÃO, M., GRANDI, T.S.M., SMÂNIA, E.F.A., SMÂNIA JÚNIOR, A. and ZANI, C.L., 2000. Biological screening of Brazilian medicinal plants. Memórias do Instituto Oswaldo Cruz, vol. 95, no. 3, pp. 367-373. http://dx.doi. org/10.1590/S0074-02762000000300012. PMid:10800195.

AMZAR, N. and IQBAL, M., 2017. The hepatoprotective effect of Clidemia hirta against carbon tetrachloride (CCL4)induced oxidative stress and hepatic demage in mice. Journal of Environmental Pathology, Toxicology and Oncology, vol. 36, no. 4, pp. 293-307. http://dx.doi.org/10.1615/ JEnvironPatholToxicolOncol.2017019824. PMid:29431062.

ANDREO, M.A., BALLESTEROS, K.V.R., HIRUMA-LIMA, C.A., ROCHA, L.R.M., BRITO, A.R.M.S. and VILEGAS, W., 2006. Effect of Mouriripusa extracts on experimentally induced gastric lesions in rodents: role of endogenous sulfhydryls compounds and nitric oxide in gastroprotection. Journal of Ethnopharmacology, vol. 107, no. 3, pp. 431-441.http://dx.doi.org/10.1016/j.jep.2006.04.001.PMid:16698206.

ARDALANI, H., AVAN, A. and GHAYOUR-MOBARHAN, M., 2017. Podophyllotoxin: a novel potential natural anticancer agent. Avicenna Journal of Phytomedicine, vol. 7, no. 4, pp. 285-294. PMid:28884079.

ARVOUET-GRAND, A., VENNAT, B., POURRAT, A. and LEGRET, P., 1994. Standardisation d'un extrait de propoliset identification des principaux constituants. Journal de Pharmacie de Belgique, vol. 49, no. 6, pp. 462-468. PMid:7884635.

ATANASOV, A.G., WALTENBERGER, B., PFERSCHY-WENZIG, E.-M., LINDER, T., WAWROSCH, C., UHRIN, P., TEMML, V., WANG, L., SCHWAIGER, S., HEISS, E.H., ROLLINGER, J.M., SCHUSTER, D., BREUSS, J.M., BOCHKOV, V., MIHOVILOVIC, M.D., KOPP, B., BAUER, R., DIRSCH, V.M. and STUPPNER, H., 2015. Discovery and respply of pharmacologically active plant-derived natural products: a review. Biotechnology Advances, vol. 33, no. 8, pp. 1582-1614. http:// dx.doi.org/10.1016/j.biotechadv.2015.08.001. PMid:26281720.

BOMFIM, E.M.S., SANTOS, T.G., CARNEIRO, A.S.O., SILVA, M.C., MARQUES, E.J. and VALE, V.L.C., 2020. Antimicrobial, antioxidant and cytotoxic activites and chemical profile of species of Miconia Ruiz \& Pav., Clidemia D. Don and Tibouchina Aubl. (Melastomataceae). Journal of Medicinal Plants Research, vol. 4, no. 1, pp. 1-6. http://dx.doi.org/10.5897/JMPR2019.6846.

BRAND-WILLIANS, W., CURVELIER, M.E. and BERSET, C., 1995. Use of a free radical method to evaluate antioxidant activity. Food Science and Technology, vol. 28, no. 1, pp. 25-30. http://dx.doi. org/10.1016/S0023-6438(95)80008-5.

CALDERÓN, A.I., TERREAUX, C., SCHENK, K., PATTISON, P., BURDETTE, J.E., PEZZUTO, J.M., GUPTA, M.P. and HOSTETTMANN, K., 2002. Isolation and Structure Elucidation of an Isoflavone and a Sesterterpenoic Acid from Henriettella fascicularis. Journal of Natural Products, vol. 65, no. 12, pp. 1749-1753. http://dx.doi. org/10.1021/np0201164. PMid:12502307.

CELOTTO, A.C., NAZARIO, D.Z., SPESSOTO, M.A., MARTINS, C.H.G. and CUNHA, H.R., 2003. Evolution of the in vitro activity of crude extracts of three Miconia species. Brazilian Journal of Microbiology, vol. 34, no. 4, pp. 339-340. http://dx.doi. org/10.1590/S1517-83822003000400010.

CLINICAL AND LABORATORY STANDARDS INSTITUTE - CLSI, 2003 [viewed 26 March 2020]. Performance standards for antimicrobial disk susceptibility tests [online]. Wayne: CLSI, 58 p. NCCLS document M2-A8, no. 23. Available from: http://www.anvisa. gov.br/servicosaude/manuais/clsi/clsi_OPASM2-A8.pdf

COE, F.G., PARIKH, D.M. and JOHNSON, C.A., 2010. Alkaloid presence and brine shrimp (Artemia salina) biossay of medicinal species of eastern Nicaragua. Pharmaceutical Biology, vol. 48, no. 4, pp. 439-445. http://dx.doi.org/10.3109/13880200903168015. PMid:20645724.
CUNHA, W.R., SILVA, M.L.A., MONTENEGRO, I.M., OLIVEIRA, A.R.A., TAVARES, H.R., SANTOS, L. and BIZÁRIO, J.C.S., 2008. In vitro. Inhibition of tumor growth by Miconia fallax. Pharmaceutical Biology, vol. 46, no. 4, pp. 292-294. http:// dx.doi.org/10.1080/13880200701741245.

CUSHNIE, T.P.T. and LAMB, A.J., 2005. Detection of galangin-induced cytoplasmic membrane damage in Staphylococcus aureus by measuring potassium loss. Journal of Ethnopharmacology, vol. 101, no. 1-3, pp. 243-248. http://dx.doi.org/10.1016/j. jep.2005.04.014. PMid:15985350.

DIANITA, R., RAMASAMY, K. and AB RAHMAN, N., 2011. Antibacterial activity of different extracts of Clidemia hirta (L.) D. Don leaves. Planta Medica, vol. 77, no. 12. http://dx.doi. org/10.1055/s-0031-1282769.

ELOFF, J.N. and MCGAW, L.J., 2006. Plant extracts used to manage bacterial, fungal, and parasitic infections in Southern Africa. In: F. AQIL, I. AHMAD and M. OWAIS, eds. Modern phytomedicine: turning medicinal plants into drugs. Weinheim: Wiley-VCH, pp. 97-121. http://dx.doi.org/10.1002/9783527609987.ch5.

FRANÇA, S.C., 2017. Bioprocessos inovadores para a produção de metabólitos ativos de plantas. In: C.M.O. SIMÕES, E.P. SCHENKEL, J.C.P. MELO, L.A. MENTZ and P.R. PETROVICK, eds. Farmacognosia: do produto natural ao medicamento. Porto Alegre: Artmed, pp. 39-52.

GONÇALVES, C., DINIS, T. and BATISTA, M.T., 2005. Antioxidant properties of proanthocyanidins of Uncaria tomentosa bark decoction: a mechanism for anti-inflammatory activity. Phytochemistry, vol. 66, no. 1, pp. 89-98. http://dx.doi. org/10.1016/j.phytochem.2004.10.025. PMid:15649515.

HARBONE, J.B., 1998. Phytochemical methods. London: Chapman \& Hall, 288 p.

JARDIM BOTÂNICO DO RIO DE JANEIRO - JBRJ, 2020 [viewed 26 March 2020]. Melastomataceae. In JARDIM BOTÂNICO DO RIO DE JANEIRO - JBRJ, ed. Flora do Brasil 2020 em construção [online]. Rio de Janeiro: JBRJ. Available from: http://www. floradobrasil.jbrj.gov.br/reflora/floradobrasil/FB161

JONES, E., EKUNDAYO, E. and KINGSTON, D., 1980. Anticancer agents XI. 2,6-dimethoxybenzoquinone as a cytotoxic constituent of Tibouchina pulchra. Journal of Natural Products, vol. 44, no. 4, pp. 493-494. http://dx.doi.org/10.1021/np50016a019.

KREIS, W., MUNKERT, J. and PÁDUA, R.M., 2017. Biossíntese de metabólitos primários e secundários. In: C.M.O. SIMÕES, E.P. SCHENKEL, J.C.P. MELO, L.A. MENTZ and P.R. PETROVICK, eds. Farmacognosia: do produto natural ao medicamento. Porto Alegre: Artmed, pp. 147-166.

LEE, J.Y. and HWANGB, W., 2004. Antioxidant and anticancer activities of organic extracts from Platycodon grandiflorum A. De Candolle roots. Journal of Ethnopharmacology, vol. 93, no. 2-3, pp. 409-415. http://dx.doi.org/10.1016/j.jep.2004.04.017. PMid: 15234786.

MARQUES, J.P. and LOPES, G.C., 2015. Alcaloides como agentes antitumorais: considerações químicas e biológicas. Revista Uningá Review, vol. 24, no. 1, pp. 56-61.

MCLAUGHLIN, J.L., CHANG, C.J. and SMITH, D.L., 1991. "Bench-top” bioassays for the discovery of bioactive natural products: an update. In: A. RAHMAN, ed. Studies in natural product chemistry. 9th ed. Amsterdam: Elsevier, pp. 383-409.

MEYER, B.N., FERRIGNI, N.R., PUTNAM, J.E., JACOBSEN, L.B., NICHOLS, D.E. and MCLAUGHLIN, J.L., 1982. Brine Shrimp: A convenient general bioassay for active plant constituents. Planta Medica, vol. 45, no. 5, pp. 31-34. http://dx.doi.org/10.1055/s-2007-971236. PMid: 17396775. 
MOREIRA, D.L., LEITÃO, S.G., GONÇALVES, J.L., WIGG, M.D. and LEITÃO, G.G., 2005. Antioxidant and antiviral properties of Pseudopiptadenia contorta (Leguminosae) and of quebracho (Schinopsis sp.) extracts. Quimica Nova, vol. 28, no. 3, pp. 421425. http://dx.doi.org/10.1590/S0100-40422005000300011.

NARASIMHAM, D., BINDU, Y.H., CHERIYAMUNDATH, S., RAGHAVAN, R., KUMARI, M.K., CHANDRASEKHAR, T. and MADASSERY, J., 2017. Evolution of in vitro anticancer and antioxidant activities from leaf extracts of medicinal plant Clidemia hirta. International Journal of Pharmaceuctical Science, vol. 9, no. 4, pp. 149-153. http://dx.doi.org/10.22159/ijpps.2017v9i4.16843.

OLIVEIRA, V.B., ZUCHETTO, M., OLIVEIRA, C.F., PAULA, C.S., DUARTE, A.F.S., MIGUEL, M.D. and MIGUEL, O.G., 2016. Efeito de diferentes técnicas extrativas no rendimento, atividade antioxidante, doseamentos totais e no perfil por clae-dad de dicksonia sellowiana (presl.). Hook, dicksoniaceae. Revista Brasileira de Plantas Medicinais, vol. 18, no. 1 suppl 1, pp. 230-239. http:// dx.doi.org/10.1590/1983-084X/15_106.

PÉREZ-CASTORENA, A.L., 2014. Triterpenes and other metabolites from Tibouchina urvilleana. Journal of the Mexican Chemical Society, vol. 58, no. 2, pp. 218-222.

PETRUCZYNIK, A., 2012. Analysis of alkaloids from different chemical groups by different liquid chromatography methods. Central European Journal of Chemistry, vol. 10, no. 3, pp. 802-835. http:// dx.doi.org/10.2478/s11532-012-0037-y.

PORTT, L., NORMAN, G., CLAPP, C., GREENWOOD, M. and GREENWOOD, M.T., 2011. Antiapoptosis and cell survival a review. Biochimica et Biophysica Acta, vol. 1813, no. 1, pp. 238-259. http://dx.doi.org/10.1016/j.bbamcr.2010.10.010. PMid:20969895.

RANI, R., ARORA, S., KAUR, J. and MANHAS, R.K., 2018. Phenolic compounds as antioxidants and chemopreventive drugs from Streptomyces cellulosae strain TES17 isolated from rhizosphere of Camellia sinensis. BMC Complementary Medicine and Therapies, vol. 18, no. 1, pp. 82. http://dx.doi.org/10.1186/s12906-0182154-4. PMid:29523107.

SOBRINHO, A.P., MINHO, A.S., FERREIRA, L.L.C., MARTINS, G.R., BOYLAN, F. and FERNANDES, P.D., 2017. Characterization of anti-inflammatory effect and possible mechanism of action of Tibouchina granulosa. The Journal of Pharmacy and Pharmacology, vol. 69, no. 6, pp. 706-713. http://dx.doi.org/10.1111/jphp.12712. PMid:28271494.

SANTOS, F.M., DE SOUZA, M.G., CROTTI, A.E.M., MARTINS, C.H.G., AMBROSIO, S.R., VENEZIANI, R.C.S., ANDRADE, M.L. and CUNHA, W.R., 2012. Evolution of antimicrobial activity of extracts of Tibouchina candolleana (Melastomataceae), isolatede compounds and semi-synthetic derivatives against endodontic bacteria. Brazilian Journal of Microbiology, vol. 43, no. 2, pp. 793-799. http://dx.doi.org/10.1590/S1517-83822012000200045. PMid:24031892.
SANTOS, V.G. and TAVARES, I.C., 2003 [viewed 26 March 2020]. Análise fitoquímica de Catigi (Clidemia hirta (L.) D. Don) como provável planta de uso medicinal pela população da ilha de Cotijuba-PA. In: Resumos do $54^{\circ}$ Congresso Nacional de Botânica [online], 13-18 July 2003, Belém, Pará, Brasil. Brasília: Sociedade Botânica do Brasil. Available from: https://dtihost. sfo2.digitaloceanspaces.com/sbotanicab/54CNBot/R0958-1.pdf

SCALBERT, A., 1991. Antimicrobial properties of tannins. Phytochemistry, vol. 30, no. 12, pp. 3875-3883. http://dx.doi. org/10.1016/0031-9422(91)83426-L.

SERNA, D.M.O. and MARTÍNEZ, J.H.I., 2015. Phenolics and polyphenolics from melastomataceae species. Molecules, vol. 20, no. 10, pp. 17818-17847. http://dx.doi.org/10.3390/ molecules201017818. PMid:26404220.

SIES, H., 1993. Strategies of antioxidant defense. European Journal of Biochemistry, vol. 215, no. 2, pp. 213-219. http://dx.doi. org/10.1111/j.1432-1033.1993.tb18025.x. PMid:7688300.

SILVA, T.B., COSTA, C.O., GALVÃO, A.F., BOMFIM, L.M., RODRIGUES, A.C., MOTA, M.C., DANTAS, A.A., SANTOS, T.R., SOARES, M.B. and BEZERRA, D., 2016. Cytotoxic potential of selected medicinal plants in northeast Brazil. BMC Complementary and Alternative Medicine, vol. 16, no. 199, pp. 1-9. http://dx.doi.org/10.1186/ s12906-016-1166-1. PMid:27391476.

SINGLETON, V.L., ORTHOFER, R. and LAMUELA-RAVENTÓS, R.M., 1999. Analysis of total phenols and other oxidation substrates and antioxidants by means of Folin-Ciocalteu reagent. Methods in Enzymology, vol. 299, pp. 152-178. http://dx.doi.org/10.1016/ S0076-6879(99)99017-1.

SOARES, S.E., 2002. Ácidos fenólicos como antioxidantes. Revista de Nutrição, vol. 15, no. 1, pp. 71-81. http://dx.doi.org/10.1590/ S1415-52732002000100008.

TROMBETTA, D., CASTELLI, F., SARPIETRO, M.G., VENUTI, V., CRISTANI, M., DANIELE, C., SAIJA, A., MAZZANTI, G. and BISIGNANO, G., 2005. Mechanisms of antibacterial action of three monoterpenes. Antimicrobial Agents and Chemotherapy, vol. 49, no. 6, pp. 24742478. http://dx.doi.org/10.1128/AAC.49.6.2474-2478.2005. PMid:15917549.

VASCONCELOS, M.A.L., ROYO, V.A., FERREIRA, D.S., CROTTI, A.E.M., SILVA, M.L.A.E., CARVALHO, J.C.T., BASTOS, J.K. and CUNHA, W.R., 2006. In vivo analgesic and antiinflammatory activities of ursolic acid and oleanolic acid from Miconia albicans (Melastomataceae). Zeitschrift fur Naturforschung. C. Journal of Biosciences, vol. 61, no. 7-8, pp. 477-482. http://dx.doi.org/10.1515/znc-2006-7803. PMid:16989305.

ZIELINSKI, A.A.F., HAMINIUK, C.W.I., ALBERTI, A., NOGUEIRA, A., DEMIATE, I.M. and GRANATO, D., 2014. A comparative study of the phenolic compounds and the in vitro antioxidant activity of different Brazilian teas using multivariate statistical techniques. Food Research International, vol. 60, pp. 246-254. http://dx.doi. org/10.1016/j.foodres.2013.09.010. 